\title{
OUTLINE
}

\section{MANAJEMEN SUMBER DAYA MANUSIA}

Topik: sumber daya manusia

Kalimat topik: manajemen sumber daya manusia

Judul: pentingnya manajemen sumber daya manusia dalam perusahaan

Kalimat pendukung:

1) Pengantar

a. Pengertian sumber daya manusia

2) Manajemen sumber daya manusia

a. Pengertian

b. Tujuan

3) Penutup

a. Rangkuman pentingnya MSDM 


\section{FACHRUDIN MUAMMAR, AMSAL MASITHA, NAZMAH ZAHIROH, RIZKA LAILATUL FITRIYA}

Program Studi Pendidikan Guru Sekolah Dasar Fakultas Keguruan dan Ilmu Pendidikan Universitas Nahdlatul Ulama Sidoarjo Email: fachrudin_mu@yahoo.com

Pengantar

Kita pasti sering mendengarkan kata sumber daya?. Sumber daya merupakan suatu tempat yang memiliki manfaat terhadap lingkungan sekitar. Secara umum sumber daya itu terbagi menjadi dua, yaitu sumber daya alam dan sumber daya manusia 
Manajemen sumber daya manusia

Manajemen sumber daya manusia sangat penting dalam pengelolaan suatu perusahaan. Maka seseorang harus mengetahui secara luas apa itu manajemen sumber daya manusia. (Pelajaran 2017) menyebutkan bahwa manajemen sumber daya manusia adalah strategi dalam menjalankan fungsi manajemen seperti planning, organizing, leading dan controlling didalam setiap aktivitasnya. Menajemen tersebut dimulai dari beberapa proses yakni proses penarikan, seleksi, sampai pemutusan hubungan kerja. Yang bertujuan untuk meningkatkan efisien, efektivitas dan produktivitas.

Ada lima macam tujuan manajemen SDM menurut Cushway, kelima macam tersebut meliputi: 
1. Membuat Kebijakan dan Pertimbangan

Kebijakan dan pertimbangan sangat penting didalam manajemen sumber daya manusiayang mana semua ini berfungsi untuk membuat perusahaan mempunyai karyawan atau pekerja dengan motivasi kerja yang tinggi. Sehingga bagian yang turun tanggan harus dipertimbangkan secara baik oleh atasan.

2. Membantu Perusahaan Dalam Mencapai Tujuan

Bagian yang bertanggung jawab dalam mengimplementasikan ataupun prosedur yang telah ditetapkan terhadap sumber daya manusia, baik dari perencanaan hingga penerapan.

3. Memberi Dukungan

Dukungan pada perusahaan ini dapat dilaksanakan dari bersama-sama. Dukungan ini sangat berguna baik dari segi manajer maupun karyawan untuk hubungan yang lebih baik. 
4. Menyelesaikan Masalah

Perencanaan yang baik dapat menyelesaikan masalah maupun krisis yang datang ataupun krisis yang mempunyai resiko negative bagi semua pekerja

5. Media Komunikasi Terbaik

Manajemen yang baik seperti berkomunikasi dapat menghubungan antara pekerja dan pekerja, pekerja dan manager, ataupun sebaliknya. Maka dalam hal ini harus ada manajemen yang digunakan untuk penyampaian pendapat (Al, 2018). Agar tujuan manajemen sumber daya manusia dapat tercapai, maka dalam suatu perusahaan diperlukan adanya hubungan yang bagus baik dari pimpinan, kepala bagian, produksi ataupun tenaga kerja lainnya. 


\section{Penutup}

Sumber daya manusia sangat penting dalam suatu perusahaan, oleh karena itu harus dirancang dengan baik agar output yang dihasilkan oleh suatu perusahaan dapat tercapai.

(Sihombing, 2016) menjelaskan pentingnya merencakakan manajemen sumber daya manusia yaitu:

1. Kebutuhan akan SDM yang Kompeten Terpenuhi

Right man right place dapat diraih oleh perusahaan dengan cara penempatakan karyawan yang handal dan tepat pada posisi kerjanya.Karena perusahaan telah mengetahui dengan baik kualitas Sumber Daya Manusia. 
2. Menghemat biaya atau dana

Tenaga yang kompeten akan
menghasilkan barang lebih baik dan lebih
cepat. maka sumber daya manusia disini
berfungsi untuk menghemat biaya. Efek
tersebut akan berguna bagi perusahaan dalam
menghemat biaya




\section{REFRENSI}

Al, Y. (2018). Tujuan MSDM Manajemen Sumber Daya Manusia dari Sumber Terpercaya. Retrieved April 11, 2018, from https://www.eduspensa.id/tujuan-msdmmanajemen-sumber-daya-manusia/

Pelajaran, T. (2017). 16 Pengertian Manajemen Sumber Daya Manusia Menurut Para Ahli Terlengkap. Retrieved April 11, 2018, from http://www.pelajaran.co.id/2017/26/16pengertian-manajemen-sumber-dayamanusia-menurut-para-ahli-terlengkap.html

Sihombing, N. (2016). Pentingnya Sumber Daya Manusia. Retrieved April 11, 2018, from https://www.kompasiana.com/nandadianats/ pentingnya-sumber-dayamanusia_5701db3bb593738b051879c6 